\title{
Addition of a new species to the genus Plectrocnemia Stephens, 1836 (Trichoptera: Polycentropodidae) from Indian Himalaya
}

\author{
Manpreet Singh Pandher* \\ Zoological Survey of India, New Alipore, Kolkata - 700053, West Bengal, India; mpandher.iari@gmail.com
}

\begin{abstract}
A new species is being described from Indian Himalaya based on the material collected during different expeditions. Plectrocnemia fischeri sp. nov is being described from Chopta (Uttarakhand). Additional material is also being represented from collections made in Himachal Pradesh, Sikkim as well as recent collection from Uttarakhand (2016) and Arunachal Pradesh (2018).

Keywords: Biodiversity, Caddisflies, Himalaya, India, Male Genitalia, Species
\end{abstract}

\section{Introduction}

Based on species Plectrocnemia senex, Stephens 1836 erected the genus Plectrocnemia Stephens. This genus is represented by approximately 175 species globally, and most of them (80 species) being confined to Oriental region (Morse, 2018). This genus is currently being represented by 8 species from India. Early contribution to this genus from India includes Ulmer (1905, 1906, one species each), Martynov (1935, three species), Fischer (1962, one species), Malicky (1993) and Oláh and Johanson (2010) contributed one species each.

\section{Material and Methods}

The adult caddisflies were collected by using light traps consisting of mercury vapour bulb as well as portable 22W UV light tube operated by battery) placed near the edge of the water streams at high altitude of the entire Himalayan belt. The caddisfly samples were killed and preserved in $70 \%$ ethyl alcohol. Pertinent collection as well as locality data was recorded for each specimen.

For identification of the species, the male genitalia were removed from the specimens and placed for overnight in $10 \% \mathrm{KOH}$. After this, the genitalia were put in $80 \%$ alcohol for observation of morphological characteristics. The illustrations of the various parts of the genitalia were prepared with the help of zoom stereoscopic binocular microscope fitted with an ocular grid in one eyepiece. Final illustrations were rendered in the black ink and scanned at 600dpi grayscale, and mounted to plates in Adobe ${ }^{\odot}$ Photoshop ${ }^{\oplus}$ 7.0. Type specimens are deposited in the National Pusa Collection (NPC) and National Zoological Collection (NZC), Zoological Survey of India.

\section{Systematics}

Plectrocnemia Stephens, 1836: 168.

Type - species Plectrocnemia senex Stephens

= Tasmanoplegas Neboiss, 1977: 64, monotypic, new synonym.

Type - species Tasmanoplegas spilota Neboiss (original designation).

Diagnostic features: The discoidal cell in each fore- and hind wing is closed, and the median cell in forewing closed. Inferior appendages are robust, short or long and frequently supplied with a pair of well-developed basodorsomesal lobes.

Remarks: The presence of a closed discoidal cell in each hind wing is the only venation character available to

\section{* Author for correspondence}


distinguish this genus from Polycentropus. However, a crossvein $s$ is present in each hind wing in some Polycentropus species as well. Some species have definite parameres, frequently divided into 2 pairs. The presence of parameres in Polycentropodidae was disputed by Schmid (1998).

\section{Plectrocnemia fischeri sp. nov. (Figures 1-5)}

Description: Adult ô; color in alcohol, dark fuscous, antenna yellowish, legs and maxillary palp brown, wings brownish hyaline, covered with black setae all over. Body clothed with small black and yellowish hairs. Length from tip of head to apex of folded forewing about $11 \mathrm{~mm}$; maxillary palp $1.75 \mathrm{~mm}$ long, segment II short, globular, segment III longer than IV, segment $\mathrm{V}$ sub equal to I-IV combined; labial palp about $0.75 \mathrm{~mm}$ long. Length of forewing about $9.25 \mathrm{~mm}$; fork-I-V present; petiole of fork-I almost equal to length of fork-I; $\mathrm{Cu}_{2}$ freely ending on $2 \mathrm{~A}+3 \mathrm{~A}$ common vein at wing apex. Hind wing $7.25 \mathrm{~mm}$ long; discoidal cell closed; fork-I present with petiole.

Male genitalia (Figures 1-5)

Sternite IX roundly three cornered in lateral view, with slightly excised cavity on each posterolateral margin; apicodorsally fused with preanal appendages; tergum IX small, slightly sclerotized, reduced to transverse band dorsally in lateral view. Tergum X very small, posterad, slightly pointed dorsoapically in lateral view. Preanal appendages each very broad, posterolaterallymesally roundly excised, setose in lateral view; broad in dorsal view, dorsobasal process of preanal appendage spine- like, curved ventrad in lateral view; arising laterally to tergum $\mathrm{X}$ in dorsal view, curved preapically. Ventral process of preanal appendage pointed, ventrad longer than dorsobasal process of preanal appendage in lateral view. Inferior appendages each sickle-shaped in lateral view, broad basally, curved apically, with broad, small basomesal process in lateral view; broad basally, constricted subapically in ventral view, setose apically. Phallic apparatus long, slender; phallotheca broad;endophallus membranous, with ventral constriction, sclerites clearly visible.
Holotype: adult, $\widehat{O}$, India: Uttarakhand; Chopta, $2600 \mathrm{~m}$, 17-vi-2010, NPIB/T/P-220, Pandher and Parey (NPC).

Paratypes: India: Himachal Pradesh; Traila, 2200m, 17-

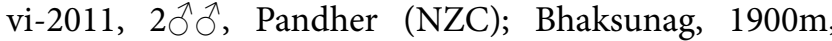
25-v-2008, 10, 19, Pandher and Parey, NPIB/T/P-223 (NPC); Panchpulla; 1800m, 20-vi-2011, 1ठ, 19, Pandher, NPIB/T/P-231, (NPC); Khajjiar, 1900 m, 16-v-2016, 10, Pandher, (NZC). Uttarakhand; Munsyari, 2400m, 20vi-2011, 1 $\hat{0}, 1+$, Pandher and Parey (NZC); Pothibasa; 1600 m, 13-vi-2016, 2ð, Pandher, (NZC). Sikkim, Chungthang, 2100m, 15-ix-2009, 10, Pandher and Parey, NPIB/T/P-222, (NPC); Gangtok, 1800m, 17-v-

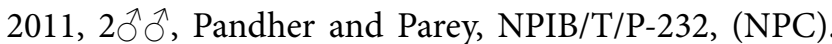
Arunachal Pradesh; Zemithang, 2200m, 16-v-2011, $10^{\lambda}$, Pandher, NPIB/T/P-233, (NPC); Lumla; 2300m, 7-x2010, 1 $\delta^{\hat{}}$, Parey and Vikram, NPIB/T/P-221, (NPC); Ramsing Forest Guest House; $850 \mathrm{~m}, 29-\mathrm{x}-2017,2{ }^{\lambda}$, Pandher and Pathania, (NZC); Migging; 900 m, 30-x2017, 10, Pandher and Pathania, (NZC).

Diagnosis: This species is closely related to Plectrocnemia banksi Fischer, 1962. However, in P. fischeri sp.nov. the preanal appendages are very broad with mesal excision on posterolateral margin in lateral new which is lacking in P. banksi.

Distribution: India: Himachal Pradesh, Uttarakhand, Sikkim, Arunachal Pradesh.

Etymology: This species is dedicated to Dr. Fischer for his contribution to Trichoptera systematics.

\section{Acknowledgements}

The author is indebted to Dr. Kailash Chandra, Director of the Zoological Survey of India, Kolkata for providing laboratory facilities as well as the inspiration for this research. Help rendered in the form of literature was provided by Dr. Hans Malicky, Austria is greatly appreciated. Financial Aid provided by the Science and Engineering Research Board (SERB), DST, Ministry of Science, is also thankfully acknowledged. Sincere words of gratitude are also due to various forest officials and District Forest Officers for providing necessary facilities during the expeditions. 


\section{References}

Fischer, F.C.J. 1962. TrichopterorumCatalogus, volume III.Ned. Entomol.Ver., Amsterdam,236 pp.

Malicky, H. 1993. Neueasiatische Köcherfliegen (Trichoptera: Philopotamidae, Polycentropodidae, Psychomiidae, Ecnomidae, Hydropsychidae, Leptoceridae). Linz. Boil. Beit.,25(2): 1099-1136.

Martynov, A.B. 1935. On a collection of Trichoptera from the Indian Museum. Part I. Annulipalpia. Rec. Ind. Mus., 37(2):93-209.

Morse, J.C. 2006. Trichoptera World Checklist. Available at: http://entweb.clemson.edu/database/trichopt/index.htm

Neboiss, A. 1977. A taxonomic and zoogeographic study of Tasmanian caddis-flies (Insecta: Trichoptera). Mem. Nat. Mus. Vict., 38: $1-208$.

Oláh, J. and Johanson, K.A. 2010. Generic review of Polycentropodidae with description of 32 new species and 19 new species records from the Oriental, Australian and Afro tropical Biogeographical Regions. Zootaxa., 2435: 1-63.

Schmid, F. 1998. The insects and arachnids of Canada, part 7. Genera of the Trichoptera of Canada and adjoining or adjacent United States.NRC Research Press, Ottawa.

Stephens, J. F. 1836. Illustrations of British Entomology; or a Synopsis of Indigenous Insects: Containing their Generic and Specific Distinctions; with an Account of their Metamorphoses, Times of Appearance, Localities, Food, and Economy, as far as Practicable. Mandibulata.Vol. VI. [Trichoptera, pp. 146-208]. Baldwin and Cradock, London, 240 pp.

Ulmer, G. 1905. Zur Kenntnisausereuropaischer Trichopteren (NeueTrichopteren des Hamburger und Stettiner Museums und des zoologischenInstituts in Halle, nebst Beschreibungeiniger Typen Kolenati's und Burmeister's). Ent. Zeitung..Entomol. Ver.zu Stettin, 66: 1-119.

Ulmer, G. 1906. Neuer Beitragzur Kenntnisausseuropaeischer Trichopteren. Notes Leyden Mus., 28: 1-116 

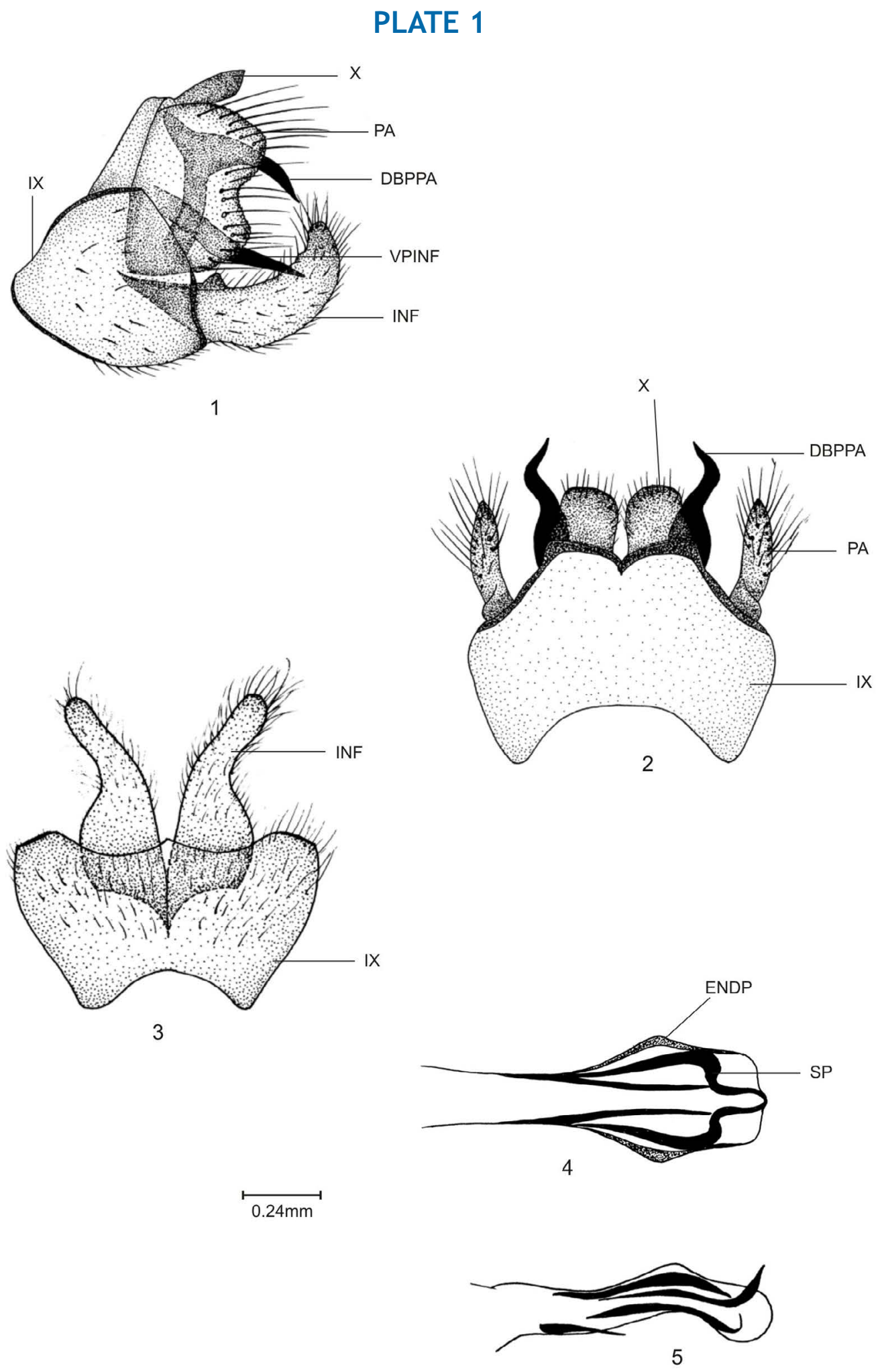

Plate 1. Figures 1-5. Male genitalia of Plectrocnemia fischeri sp.nov. 1. Lateral view, 2. Dorsal view, 3. Ventral view, 4. Phallus, ventral view, 5. Phallus lateral view. (DBPPA-Dorsobasal process of preanal appendage, ENDP-Endophallus, INF-Inferior appendage, PA-Preanal appendage, SP-Spine, VPINF-Ventral process of inferior appendage). 